\title{
Epidemioclinical Aspects of the Oral Cavity Cancers in Ziguinchor, South of Senegal
} \author{
Diom Siga Evelyne ${ }^{2}$ and Diallo Bay Karim ${ }^{5}$ \\ ${ }^{1}$ ENT and Cervicofacial Surgery Department, Senegal Peace Hospital, Senegal \\ ${ }^{2}$ Stomatology and Oral Surgery Department, General Hospital Idrissa Pouye, Senegal \\ ${ }^{3}$ ENT and Cervicofacial Surgery Department, Dakar Principal hospital, Senegal \\ ${ }^{4}$ ENT and Cervicofacial Surgery Department, Regional Hospital of Ziguinchor, Senegal \\ ${ }^{5}$ ENT and Cervicofacial Surgery Department, Albert Royer Children's Hospital, Senegal
}

Ndadi Tchiengang K Junie ${ }^{1}$ and Messina Ebogo Wilfried ${ }^{2}$, Kizonde Yannick Kalungwe ${ }^{3}$, Diallo Mamadou Talibé ${ }^{4}$,

Submission: March 15, 2021; Published: April 20, 2021

*Corresponding author: Ndadi Tchiengang K Junie, ENT Department, Peace Hospital, Ziguinchor, Senegal

\section{Abstract}

Introduction: The oral cavity cancer or oral cancer (OC) is a malignant neoplasia that is part of the UADT's cancers (Upper aero digestives tract). It represents 25 to $30 \%$ on average. Tobacco, potentiated by alcohol, remains the main risk factor. Men seem to be twice as affected as women are and nearly $95 \%$ of patients are between 40 and 60 years old. The objective of this study was to determine the epidemioclinical profile of the oral cavity cancers in Ziguinchor in southern Senegal.

Patients and Methodology: We conducted a retrospective transversal study in the ENT and cervicofacial surgery department of the Ziguinchor Regional Hospital over a period of 10 years. Our target population consisted of patients of all ages whose records showed oral cavity cancer with histological confirmation. Data were recorded and analyzed using IBM statistical package for social (SPSS) version 24.0 software.

Results: This study included 20 patients that have oral cavity cancer with histological confirmation. The ages of the patients ranged from 17 years to 78 years. Female subjects were the most numerous, at $80 \%(n=16)$ of the total population. Eighty percent $(n=16)$ of the subjects presented a macroscopic aspect of ulcerative budding tumor. Forty-five percent $(n=9)$ of the patients received were smoking and $45 \%(n=9)$ of the patients combined tobacco and alcohol. Squamous cell carcinoma was the only histological type found. It was well differentiated in $50 \%$ (of the cases $(\mathrm{n}=10)$, only in women.

Conclusion: oral cavity cancers present epidemio clinical particularities in Ziguinchor. Indeed, in our context, they affect women more than men. The therapeutic attitude towards this clinical entity must consider the specificities of the population. These new data are helping to update data on UADT's cancer in Senegal.

Keywords: Cancer; Oral cavity; Ziguinchor; Senegal

\section{Introduction}

Oral cavity cancer or oral cancer (OC) is one of the ten most common cancers in the world with delayed diagnosis, poor prognosis, no specific biomarkers for the disease and expensive treatment modalities for patients [1]. These cancers are generally part of upper aero digestive tract's cancers (UADT) and represent on average 25 to $30 \%$ of UADT's cancers [2,3]. They are dominated by squamous cell carcinoma that constitutes $90 \%$ of the oral cavity cancers [3]. The main risk factors are alcohol and tobacco consumption whose effects are synergistic, but also so-called precancerous lesions $[3,4]$. Other viral factors such as human papillomavirus (HPV), infection, nutritional factor, poor oral health and genetic disposition are mentioned $[3,5,6]$. The oral cavity is the most frequent location of upper aero digestive tract' cancers (UADT) [4]. Men seem to be twice as affected by oral 
cancer than women. Nearly $95 \%$ of patients are between 40 and 60 years old, [7] but an African study reported an increasing number of relatively young subjects [8]. In Ziguinchor, south of Senegal, we conducted a study aimed to determine the epidemioclinical profile of oral cavity cancer.

\section{Patients and methods}

We conducted a retrospective transversal study in the ENT and cervicofacial surgery department of the Ziguinchor Regional Hospital in southern Senegal. Our study took place over a 10-year period from January 1, 2010 to December 31, 2020. Our target population was patients of all ages with histological confirmation of oral cavity cancer. The variables studied were grouped into epidemiological and clinical parameters. They were sex, age, risk factors, macroscopic aspect of the lesion, site of cancer and histological aspect of the lesion.

\section{Collection of data}

This was to collect epidemiological and clinical information from patients meeting our selection criteria. This collection was carried out from the medical record of patients, registers of operating reports and archives retained for this research.

\section{Statistical analysis}

The data from this study were analyzed and coded using the EPI INFO version 7.7.2 software. The charts were constructed using Microsoft Office Excel 2013 and SPSS software. The intervariable associations were determined using the $\mathrm{chi}^{2}$ test. The correlation coefficient was evaluated with Spearman's test and the statistical significance level was set at 0.05 .

\section{Ethical considerations}

Not required for this retrospective study. The database has been kept in a secure location accessible only to medical personnel.

\section{Results}

This study included 20 patients with oral cavity cancer with histological confirmation. Female subjects represented $80 \%$ ( $n=$ $16)$ and male subjects represented $20 \%(n=4)$ for a sex ratio of 0.25 . The average age of the patients in this series was 31.91 years \pm 11.380 with extremes of 17 years and 78 years. Risk factors were found in our investigation. Indeed, $45 \%(\mathrm{n}=9)$ of patients were exposed to active smoking and $45 \%(n=9)$ of them associated tobacco with alcohol. We found $10 \%(\mathrm{n}=2)$ of patients with poor oral hygiene marked by severe periodontitis. The macroscopic aspect of the lesion (Table 1) was an ulcerative bud lesion in 55\% $(n=11)$ of patients. All the males exhibited only an ulcerativebudding aspect. Pearson's Chi2 P-value is 0.024 . The most affected oral cavity site was the movable tongue in $35 \%(n=6)$ of patients (Figure 1). All oral cavity cancers in this study were squamous cell carcinomas. Squamous cell carcinoma was well differentiated in $50 \%$ (of the cases $(n=10)$, only in women (Table 2 ).

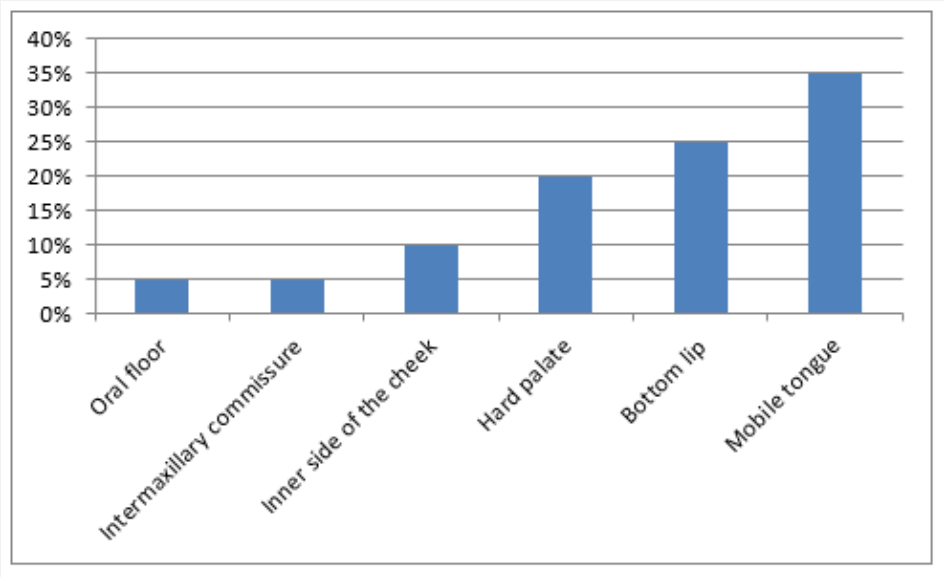

Figure 1: Distribution of patients according to the site of the lesion.

Table 1: Distribution of the macroscopic aspect of the lesion according to sex.

\begin{tabular}{|c|c|c|c|}
\hline \multirow{2}{*}{ Macroscopic Aspect of the Lesion } & \multicolumn{2}{|c|}{ Gender } & \multirow{2}{*}{ Total } \\
\cline { 2 - 4 } & Women & 0 & 7 \\
\hline Budding lesion & 7 & 0 & 2 \\
\hline Granulomatous lesion & 2 & 4 & 11 \\
\hline Ulcerative budding lesion & 7 & & 7 \\
\hline
\end{tabular}


Table 2: distribution of the histological aspect of OCs according to sex.

\begin{tabular}{|c|c|c|c|}
\hline \multirow{2}{*}{ Histological Aspect } & \multicolumn{2}{|c|}{ Sex } & \multirow{2}{*}{ Total } \\
\hline & Women & Men & \\
\hline Well-differentiated and invasive squamous cell carcinoma & 10 & 0 & 10 \\
\hline Keratinizing and infiltrating moderately differentiated squamous cell carcinoma & 6 & 1 & 7 \\
\hline Poorly differentiated and invasive squamous cell carcinoma & 0 & 3 & 3 \\
\hline
\end{tabular}

\section{Discussion}

We have collected 20 patients with oral cavity cancer of whom 16 are female. Women represented so $80 \%$ of our study population. Bambara and al reported this female predominance. They stated that in Burkina Faso, oral cavity cancer affects two women for every man [9]. Kayembé in Congo [10] also reported this female predominance and in similar proportions. These results differ considerably from the data in the literature, which is almost unanimous on the male predominance of this cancer [11]. We have therefore explored certain hypotheses that could explain this female predominance in the context of our research. The average age of the patients in our study was 31.91 years \pm 11.380 with a minimum of 17 years and a maximum of 78 years. However, CO is considered to occur mainly in the old persons [12]. Most cases occur between the ages of 50 and 70 [12]. However, it can occur in young children in the absence of any known risk factor [13].

The tongue is the most frequent oral tumor location in many countries, of all sexes [14]. In Asia, it is the most frequently affected site and accounts for $42 \%$ of all oral cavity sites [15]. The tongue with the oral floor constitutes the elective locations for the development of squamous cell epitheliomas within the oral cavity. In our study, the mobile tongue was also the preferred site of OC. On the other hand, a Senegalese study rather reported the mandible as the most affected site oral cavity cancer [8]. Risk factors were found in our investigation. Indeed, some of our patients were smokers while others associated tobacco with alcohol. The main risk factors for these tumors of the oral cavity are the consumption of alcohol and tobacco, the effects of which are synergistic and not additional [3]. Tobacco consumption associated with a daily intake of alcohol, in particular superior to $50 \mathrm{~g}$, has an almost multiplying effect on the risk of developing UADT squamous cell carcinoma [3].

Regarding tobacco, Bambara reported in his study that men and women used tobacco in similar proportions, but the consumption method was different. In fact, the men smoked it while the women chewed it [9]. Indeed, chewing tobacco, which consists of placing a portion of tobacco between the lower lip and the teeth to extract the juice while rejecting the excess, has also been described in the literature [16]. Chewing tobacco consumers electively present mucous lip lesions or inner face of the cheeks by direct contact with carcinogens [3] Tobacco chewing is also a risk factor more important for OCs than smoking. This is a very common practice in India. [16]. In our study, the high prevalence of OCs in females could be explained by tobacco chewing habits.

The oral cavity, oropharynx and hypopharynx are elective targets for the action of alcohol in the UADT [3]. A prospective study in India showed that alcohol consumption increased the incidence of OCs by $49 \%$ among current alcoholics and by $90 \%$ among former drinkers $[17,18]$. This could be due to the residual effect of alcohol consumption or those who have given up the habit due to serious illness. Consumption of alcoholic beverages was associated with an increased risk of 00 in men (OR 2.2) but this was not the case in women in the study by Balaram, South India [19].

Chronic iron deficiency is responsible for stomatitis that can secondarily degenerate into tongue cancer [3]. Vitamin deficiencies due to isolated malnutrition or in the context of chronic alcoholism probably facilitate the occurrence of the oral cavity cancer. The poor oral health often cited as a risk factor for oral cavity cancer is frequently included in the context of alcoholtobacco poisoning [3]. None of these factors was found in our study.

The macroscopic aspect of the lesion was an ulcerative budding lesion in $55 \%(n=11)$ of the patients while the lesion was budding in $30 \%(n=6)$ of the survey subjects. Pearson's Chi2 $\mathrm{P}$-value is 0.024 . This P-value shows that there is a significant difference between macroscopic aspect and gender. In Faissal's study [20] the predominant macroscopic aspect was the ulcerative budding lesion (38\%) followed by the budding lesion. This result is like that found in our search.

More than $90 \%$ of oral cavity cancers are squamous cell carcinomas, arising from the covering mucosa. The remaining fraction is composed for the most part of carcinomas developed from the accessory salivary glands, and much more rarely by lymphomas or rare tumors arising from the tissues underlying the mucosa [3]. The only histological type found in our study was squamous cell carcinoma.

\section{Limitations of the Study}

The diagnostic difficulties of UADT cancers encountered in Ziguinchor would explain the small size of our sample. In fact, a study on UADT cancers in southern Senegal reported a rate of $57.61 \%$ histological confirmation over a 10 -year period [21]. 
The UADT cancers are initially pauci-symptomatic, and the definitive diagnosis is pathological [22]. This histological result is a prerequisite for the study of oral cavity cancer and pharynx [23].

\section{Conclusion}

The oral cavity cancers are the most common malignant tumors in UADT. Our study carried out in the south of Senegal strengthens a first Senegalese study on oral cavity cancers, carried out 16 years ago. Indeed, in our context, they affect women more than men. Risk factors such as exposure to tobacco and alcohol were reported in this study. The difference in smoking patterns could explain the greater exposure of women. The therapeutic attitude towards this clinical entity must consider the specificities of the population. This study contributes to updating the data on UADT cancers in Senegal and particularly those of the oral cavity.

\section{References}

1. César R (2015) Essentials of oral cancer. int J Clin Exp Pathol 8(9): 11884-11894.

2. Aupérin A, Hill C (2005) Epidemiology of upper aero digestive tract carcinomas. Cancer Radiother 9: 1-72.

3. Barthélémy I, Sannajust JP, Revol P (2005) Oral cavity cancers. Preamble, epidemiology, clinical study. EMC-Stomatology 1: 277-294.

4. Paré A, Joly A (2017) Oral cavity cancers: risk factors and treatment. Press Med.

5. Mork J, Lie AK, Glattre E, Hallmans G, Jellum E, et al. (2001) Human papillomavirus infection as a risk factor for squamous-cell carcinoma of the head and neck. N Engl J Med 344(15): 1125-1131.

6. Zygogianni AG, Kyrgias G, Karakitsos P (2011) Oral squamous cell cancer: early detection and the role of alcohol and smoking. Head Neck Oncol 3: 2.

7. Silverman SJ (2003) Oral Cancer. Ganster TS, BC Decker Inc, Spain p. $1-2$.

8. Stoure, Sonko L, Diallo BK (2005) Epidemiological profile of the oral cavity cancers in Senegal. Journal of Stomatology and Maxillofacial Surgery 106(4): 68-68.

9. Augustin TB, Mathieu M, Tarcissus K (2015) Cancers of the oral cavity: predominantly female condition in Ouagadougou. Med Buccale Chir Buccale 21(2).
10. Kayembé MK, Kalengayi MM (1999) Histological and epidemiological profile of oral cancer in Congo (Zaire). Odontostomatol Trop 22(88): 29-32.

11. Jemal A, Bray F, Center MM, Frelay J, Ward E, et al. (2011) Global Cancer Statistics. CA Cancer J Clin 61(2): 69-90.

12. Bhurgri Y, Bhurgri A, Usman A, Pervez S, Kayani N, et al. (2006) Epidemiological review of head, neck cancers in Karachi. Asian Pac J Cancer Prev 7(2): 195-200.

13. Khan MH, Naushad QN (2011) Oral squamous cell carcinoma in a 10-year-old boy. Mymensingh Med J, 20(1): 145-150.

14. Sutandyo N, Ramli R, Sari L, Soeis DS (2014) Profile and survival of tongue cancer patients in "Dharmais" Cancer Hospital, Jakarta. Asian Pac J Cancer Prev 15(5): 1971-1975.

15. Sherin N, Simi T, Shameena PM, Sudha S (2008) Changing trends in oral cancer. india J Cancer 45: 93-96.

16. Jayalekshmi PA, Gangadharan P, Akiba S, Nair RRK, Tsuji M, et al. (2009) Tobacco chewing and female oral cavity cancer risk in Karunagappally cohort, India. Br J Cancer 100(5): 848-852.

17. Lin WJ, Jiang RS, Wu SH, Chen FJ, Liu AS (2011) Smoking, alcohol, betel quid, oral cancer: a prospective cohort study. J oncol 2011: 525976.

18. Cancela M de C, Ramadas K, Fayette JM, Thomas G, Richard M, et al. (2009) Alcohol intake, oral cavity cancer risk among men in a prospective study in Kerala, India. community Dent Oral Epidemiol 37(4): 342-349.

19. Balaram P, Sridhar H, Rajkumar T, Vaccarella S, Rolando H, et al. (2002) Oral cancer in southern India: the influence of smoking, drinking, paanchewing, oral hygiene. Int J Cancer 98(3): 440-445.

20. Faissal B (2017) Oral cavity cancers: retrospective epidemiological and clinical study of 70 cases. Doctoral thesis in medicine. Faculty of Medicine of Marrakech, Cadi Ayad University, Morocco.

21. Ndadi TKJ, Senghor F, Randriamalala NA, Diallo MT, Evelyne DS, et al (2021) Treatment Problem of the Upper Aero Digestive Tract's Cancers at the Regional Hospital Center of Ziguinchor in Southern Senegal. Glob J Oto 24(1): 556127.

22. Ndadi Tchiengang KJ, Thioubou A, Senghor F (2020) Diagnostic wandering about a case of squamous cell carcinoma of the hypopharynx. Jaccr Africa 4(3): 632-633.

23. Rakotoarivony AE, Rakotoarison RA, Razanakoto FA (2014) Malignant tumors of the oral cavity and pharynx: an 11-year study at the Soavinandriana Hospital Center, Antananarivo, Madagascar, 4(2).

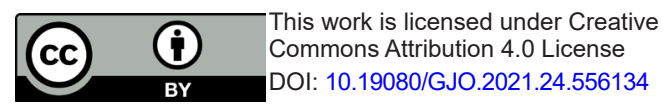

\section{Your next submission with Juniper Publishers will reach you the below assets}

- Quality Editorial service

- Swift Peer Review

- Reprints availability

- E-prints Service

- Manuscript Podcast for convenient understanding

- Global attainment for your research

- Manuscript accessibility in different formats

( Pdf, E-pub, Full Text, Audio)

- Unceasing customer service

Track the below URL for one-step submission https://juniperpublishers.com/online-submission.php 